Article

\title{
Energy Performance of a Light Wood-Timber Structured House in the Severely Cold Region of China
}

\author{
Meng Zhen ${ }^{1}$ and Bin Zhang ${ }^{2, *}$ \\ 1 Department of Architecture, School of Human Settlements and Civil Engineering, Xi'an Jiaotong University, \\ Xi'an 710049, China; zhenmeng@xjtu.edu.cn \\ 2 Department of Building Environment and Energy Engineering, School of Architecture, \\ Harbin Institute of Technology, Harbin 150006, China \\ * Correspondence: $13945693405 @ 126 . c o m ;$ Tel.: +86-13945693405
}

Received: 14 February 2018; Accepted: 7 May 2018; Published: 9 May 2018

\begin{abstract}
The purpose of the study was to determine the energy performance of a timber structured house built in Harbin, a severely cold region of China. The research team conducted a field test on the house that lasted three months (15 January-15 April 2008). The test included the winter heating energy consumption, average indoor temperature and relative humidity, building heat storage capacity, heat transfer coefficient of the wall, total air volume of air-conditioning system, etc. The test results showed that the total heating was calculated to be $73,240.59 \mathrm{MJ}$ in winter. Thermal imaging tests were carried out on the house and found no obvious thermal defects such as thermal bridges. In conclusion, the timber structured house has a good level of building energy conservation and would provide a good exemplary for green building design and construction in similar severely cold regions in the world.
\end{abstract}

Keywords: timber structured house; severely cold region; energy consumption; energy conservation; energy efficiency

\section{Introduction}

Lightweight wood timber structured houses have the advantages of environmental protection, energy saving, flexible design, comfort and convenience. Ancient buildings in China were built using wood-timber for a thousand years, and some of these buildings are still in use now. The timber structure is easy to maintain and remodel. At the same time, light wood house has a good durability, fire resistance and thermal insulation performance, whose advantages are reflected in two aspects: (1) The lightweight wood is a natural insulating material, and the honeycomb structure of the wood makes the insulation performance much better than heavy steel and concrete materials. (2) The lightweight wooden keel within the cavity (within the cavity wall, roof and floor) can be filled with glass fiber and mineral wool insulation materials to further improve the heat insulation performance. Lightweight wood-timber structural materials' thermal properties are about 400 times better than steel and 16 times more than concrete. In a $150 \mathrm{~mm}$ thick wooden wall, the heat insulation performance is equivalent to $610 \mathrm{~mm}$ thick brick wall [1].

In China, reinforced concrete has been mostly used to build residential buildings and lightweight timber structures are rarely considered. However, the lightweight timber structures could achieve three advantages: (1) reduce construction wastes caused by demolition of buildings; (2) improve the service life of buildings; and (3) reduce building energy consumption and improve living quality and thermal comfort level for building occupants.

Scholars have conducted in-depth studies on lightweight wooden structure for residential buildings. In terms of thermal storage capacity of wood-timber house, researchers found that it needs to be improved [1], 
but it has better thermal performance than brick house [2], and it impacts the energy consumption. Yu et al. tested it using Passivhaus Projektierungs Paket (PHPP) and found that one wood-timber house consumes $70 \mathrm{kWh} / \mathrm{m}^{2}$ in winter [3]. If we solve the thermal bridge, wood-timber house can have a better thermal performance [4]. In the whole life cycle, wood-timber is much more environmentally friendly than cement; it can reduce $35 \%$ of future emissions of a house [5-7]; and it can reduce carbon footprint [8,9]. In terms of house structure, studies show that it can provide a safe and suitable place to live and is suitable to cold climate $[10,11]$. Some researchers give optimized design of wood-timber house by architectural design [12-16].

Scholars have analyzed the structure, life cycle, carbon footprint, energy structure and other aspects of wood-timber house using simulation and literature review. However, there is currently a lack of a comprehensive analysis on the heating energy consumption, heat transfer coefficient and usage of air-conditioning system in winter in timber frame houses, especially in the severely cold regions of the world. In this work, the energy consumption of a lightweight timber house located in Harbin, China $\left(45^{\circ} 41^{\prime} \mathrm{N}\right.$, $126^{\circ} 37^{\prime}$ E) was studied by means of on-site energy consumption measurement. The purpose of this study was to evaluate the energy consumption in a light-wood house and determine whether it can meet China's building energy efficiency standards as well as whether it could maintain the indoor thermal comfort of occupants. The central air conditioning was an independent residential use type system. The indoor temperature could be automatically adjusted. The house was unoccupied during the test to test the accuracy of the energy consumption in an unoccupied house.

\section{Research Methods}

\subsection{Description of the Lightweight Wood-Timber House}

The lightweight wood-timber house is located in Harbin, China $\left(45^{\circ} 41^{\prime} \mathrm{N}, 126^{\circ} 37^{\prime} \mathrm{E}\right)$. This area is situated in severely cold region of China. The average annual temperature is $3.6^{\circ} \mathrm{C}$. The coldest month is January and the minimum temperature is $-38.1{ }^{\circ} \mathrm{C}$ and the number of heating days is 176 . According to the indoor reference temperature of $18^{\circ} \mathrm{C}$, the number of heating days is $4928^{\circ} \mathrm{C} /$ day. The heat consumption index is $21.9 \mathrm{~W} / \mathrm{m}^{2}$.

The house is south facing orientation. It is $6.29 \mathrm{~m}$ tall and has two floors. The first floor is $3.64 \mathrm{~m}$ and the second floor is $2.65 \mathrm{~m}$. The building energy consumption calculation area is $196.75 \mathrm{~m}^{2}$. The building area is $189.18 \mathrm{~m}^{2}$. The building surface area is $532.58 \mathrm{~m}^{2}$ and building volume is $735.94 \mathrm{~m}^{3}$. The building volume factor is 0.63 . The building is shown in Figure 1. The main wall structure is shown in Figure 2. The details of windows and wall areas of the house are shown in Table 1 and the structural details are shown in Table 2.

Table 1. Residential window to wall ratio of wood structure.

\begin{tabular}{ccc}
\hline Orientation of Window & Actual Window to Wall Ratio & Standard Prescribed Limit of Window to Wall Ratio \\
\hline East & 0.09 & 0.30 \\
South & 0.14 & 0.35 \\
West & 0.02 & 0.30 \\
North & 0.07 & 0.25 \\
\hline
\end{tabular}

Table 2. Timber structure of the residential house.

\begin{tabular}{cl}
\hline Construction Element & \multicolumn{1}{c}{ Composition } \\
\hline Roofing & $\begin{array}{l}\text { Light wood truss is filled with ultra-fine glass wool felt }(160 \mathrm{~mm})+ \\
\text { plywood }(12 \mathrm{~mm})+\text { roof tile material }\end{array}$ \\
\hline \multirow{2}{*}{ Exterior wall } & $\begin{array}{l}\text { Gypsum board }(12.7 \mathrm{~mm}) \text { and wall pillar }(38 \mathrm{~mm} \times 140 \mathrm{~mm}) \text { are } \\
\text { filled with ultra-fine glass wool felt }(160 \mathrm{~mm})+\text { structural wall } \\
\text { panels }(\text { OSB board } 9 \mathrm{~mm})+\text { polystyrene foam }(30 \mathrm{~mm})+ \\
\text { waterproof breathable membrane } \mathrm{mm}+\text { air layer }(25 \mathrm{~mm})+\mathrm{red} \\
\text { brickwork }(90 \mathrm{~mm})+\text { cement mortar }(20 \mathrm{~mm}) .\end{array}$ \\
\hline
\end{tabular}


Table 2. Cont.

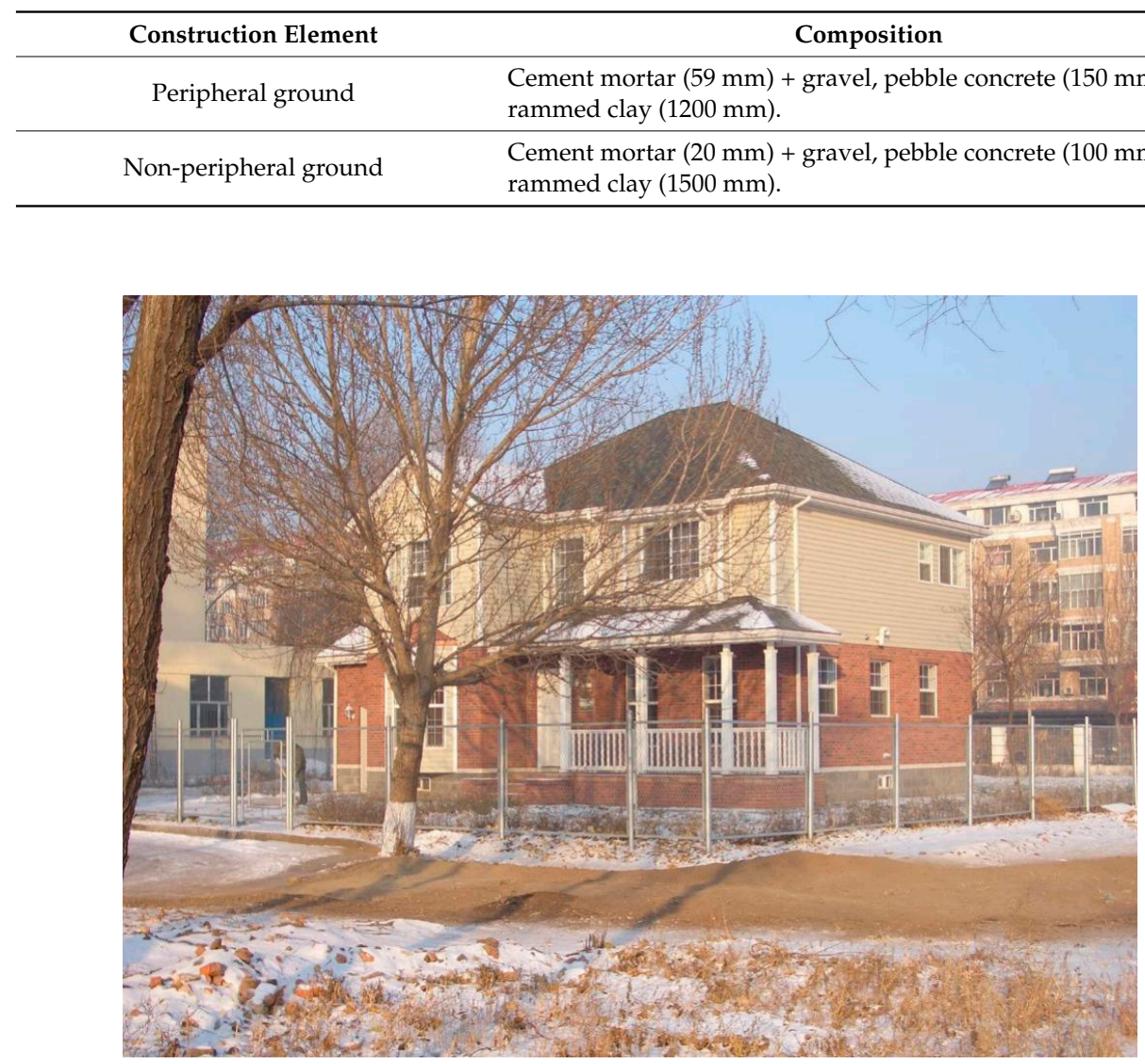

Figure 1. Light-wood structure residence in Harbin.

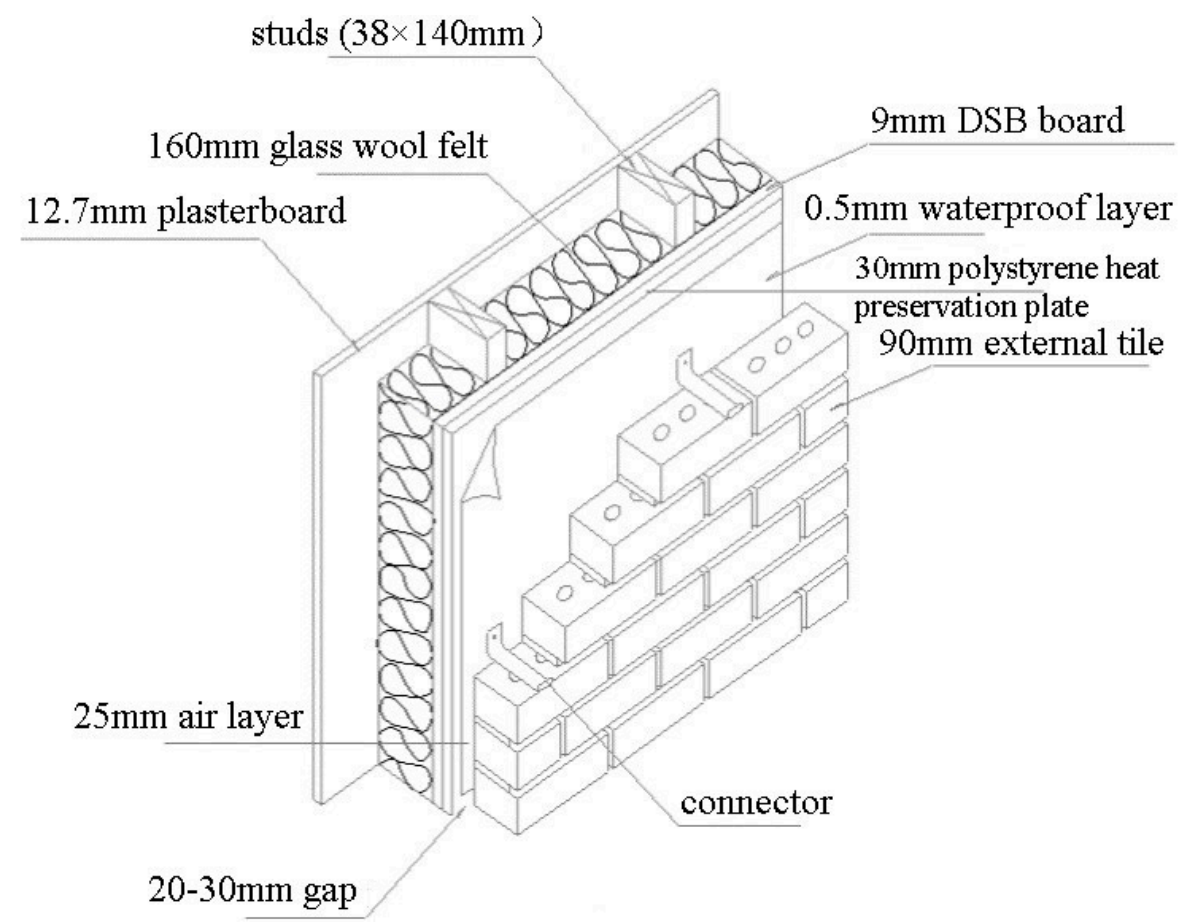

Figure 2. The structure of the main wall. 


\subsection{Test Program}

The study of heating energy consumption is divided into three stages: the first stage of preparation, during 15-25 January 2008, was mainly to test and debug installed instruments, and try to discover and eliminate problems during the test.

The second stage of the test was continuous tracking test from 25 January to 15 April 2008. The following six items were monitored: (1) total heating quantity and average energy consumption; (2) the indoor/outdoor air temperature; (3) the indoor/outdoor relative humidity; (4) the heat transfer coefficient of the building enclosure structure as well as the thermal performance of doors and windows; (5) the surface temperature distribution of thermal bridge; and (6) the parameters of the residential air-conditioning system. The layout is shown in Figures 3 and 4.

The data analyses were conducted in the third phase of the program. By analyzing the test data, the energy-saving performance of wood-timber house was determined

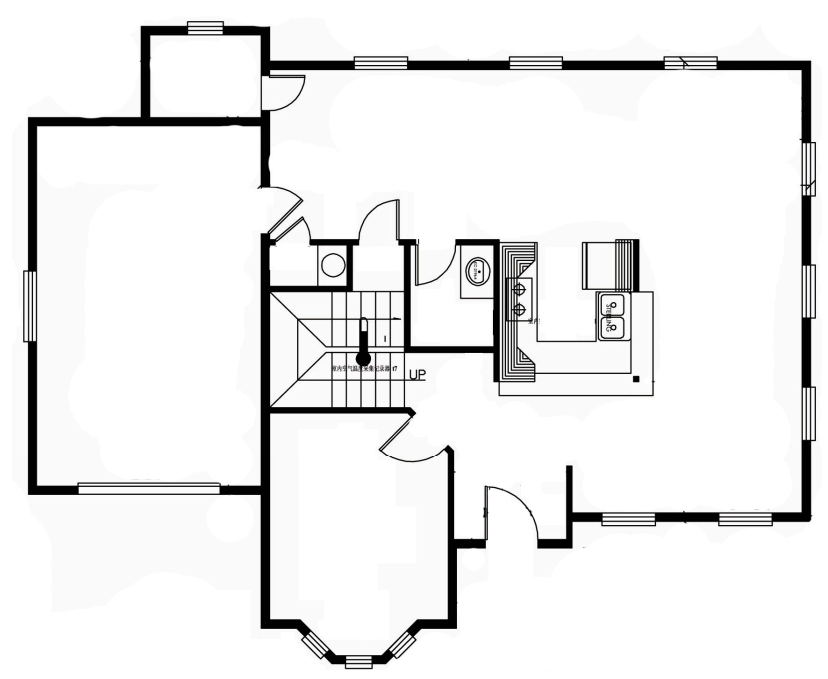

Figure 3. The first floor of light wood-timber house.

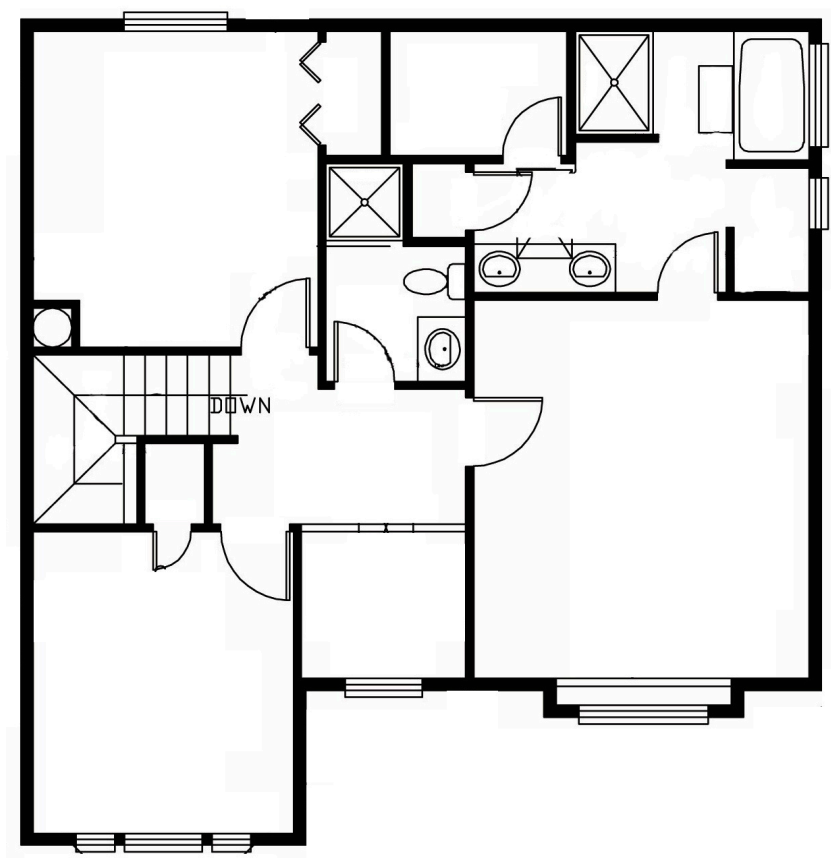

Figure 4. The second floor of light wood-timber house. 


\subsection{The Standards and Instrument}

The standards used for the monitoring of the building thermal performance was based on China building energy efficiency standard [17].

The instruments used included: 62 BES-01 temperature acquisition recorders, 20 BES-02 temperature and humidity acquisition recorders, 2 BES-G intelligent multi-channel temperature and heat flow testers, 2 sets of BES-E ultrasonic heating for the field detector, 1 set of QDF-2A thermal ball anemometer and 1 set of FLUKE Ti30 infrared imaging instrument.

\section{Results and Discussion}

\subsection{Unit Heating Energy Consumption}

During the test of the heat consumption of buildings with centralized heating, the following parameters were determined within the scope of the building: (1) the total heat supply of the building at the heating entrance; (2) the average indoor temperature of the building; and (3) the average outdoor temperature. The average outdoor temperature during the test duration was calculated according to Equation (1):

$$
t_{e a}=\frac{\sum_{i=1}^{m} \sum_{j=i}^{n} t_{e_{i, j}}}{m \times n}
$$

where $t_{e a}$ is the average outdoor temperature during the monitoring period, ${ }^{\circ} \mathrm{C} ; t_{e i, j}$ is the $j$ hourly measurement value of the $i$ temperature measuring point, ${ }^{\circ} \mathrm{C} ; m$ is the number of outdoor temperature measuring point; $n$ is the total number of hourly measurements for a single temperature point; $i$ is the number of outdoor temperature measurement points; and $j$ is the sequence number of the measured value of outdoor temperature in $i$ point.

The building heat supply test can be used by temperature sensors, flow meters and corresponding secondary instruments. When using the flow meter method to test the heat supply, the heating system must be continuously and stably operated. We used the flow meter method to test indoor and outdoor air temperature, supply and return water temperature, flow and other content, with ultrasonic flow test equipment, at a flow measurement accuracy of $\pm 5 \%$. The flow meter method should be tested according to the following methods: (1) installation temperature and flow test instruments, data acquisition instruments and heat metering instruments; and (2) the time interval for recording data should not exceed $30 \mathrm{~min}$.

Building supply heat (MJ) was calculated using Equation (2):

$$
Q_{g}=4.19 \times 10^{-3} \sum G_{i}\left(t_{g n}-t_{h n}\right) \Delta T
$$

where $G_{i}$ is the water-flow supply at every time interval, $\mathrm{kg} / \mathrm{h} ; t_{g n}$ is the water temperature supply at every time interval, ${ }^{\circ} \mathrm{C}$; $t_{h n}$ is the return water temperature at every time interval, ${ }^{\circ} \mathrm{C}$; and $\Delta T$ is the time interval during the test, $\mathrm{h}$.

The instrument for testing water temperature should adopt excellent (class I or II) thermocouple, the total uncertainty of the test should be less than $5 \%$.

The heating consumption of the building unit should be calculated according to Equation (3) when testing under uninhabited conditions:

$$
q_{h m}=\frac{Q_{h m}}{A_{0}} \times \frac{t_{i}-t_{e}}{t_{i a}-t_{e a}} \times \frac{278}{H_{r}}-q_{I H}
$$

where $q_{h m}$ is the unit heating energy consumption, $\mathrm{W} / \mathrm{m}^{2} ; Q_{h m}$ is the total heat quantity measured at the thermal entrance to the building for the duration of the test, $\mathrm{MJ} ; q_{I H}$ is the unit building area of the building interior heat gain, $\mathrm{W} / \mathrm{m}^{2}, 3.8 \mathrm{~W} / \mathrm{m}^{2} ; t_{i}$ is the average room temperature of all rooms, $16{ }^{\circ} \mathrm{C} ; t_{e}$ is the the average outdoor temperature of the heating period, $-10.0{ }^{\circ} \mathrm{C} ; t_{i a}$ is the average temperature of indoors in a continuous time, ${ }^{\circ} \mathrm{C} ; t_{e a}$ is the average temperature of outdoors in a 
continuous time, ${ }^{\circ} \mathrm{C} ; A_{0}$ is the total area of the building heating, $\mathrm{m}^{2} ; H_{r}$ is the duration, $\mathrm{h}$; and 278 is the unit conversion factor.

The heating consumption can be determined by the theoretical calculation. Then, the heat consumption of the heat transfer coefficient can be calculated from data obtained from field measurements. Finally, the heat consumption of the building units can be obtained by heat measurement and measurement of indoor and outdoor average temperature. Through the above calculation and comparison, the theoretical calculation and actual measurement were shown to have a good comparison. Therefore, the calculation of heat consumption can provide a good indicator of the actual consumption of the house in the future. The statistical bar chart of the weekly amount of heating used in the lightweight wood timber house is shown in Figure 5. The heating consumption is shown in Figure 6. The energy consumption results are shown in Table 3. In Figure 5, the first week consumed the most energy, because the house needed to be warmed. When the temperature is stable, e.g. Week 7, the energy consumption is stable, nearly $2000 \mathrm{MJ}$ per week, and it is much less than Week 1. In Figure 6, the measured value is higher than converted value in Weeks 1-6, and converted value is higher than measured value in Weeks 7-12, because, when the room temperature is stable, the building energy consumption is reduced to normal, thus the measured value is less than the converted value. In Table 3, the energy consumption of buildings is $24.61 \mathrm{~W} / \mathrm{m}^{2}$, which is lower than the energy consumption of ordinary buildings (more than $28 \mathrm{~W} / \mathrm{m}^{2}$ ). This shows that wood-timber house can provide a low energy consumption and high comfort environment.

Table 3. The calculated and measured energy consumption of lightweight wood timber house.

\begin{tabular}{cccccc}
\hline $\begin{array}{c}\text { Theoretical Heat } \\
\text { Consumption } \\
\left(\mathbf{W} / \mathbf{m}^{2}\right)\end{array}$ & $\begin{array}{c}\text { Heat Consumption } \\
\text { of Heating after the } \\
\text { Monitoring }\left(\mathbf{W} / \mathbf{m}^{2}\right)\end{array}$ & $\begin{array}{c}\text { Measured Heating } \\
\text { Consumption } \\
\text { during Monitoring } \\
\left(\mathbf{W} / \mathbf{m}^{2}\right)\end{array}$ & $\begin{array}{c}\text { Unit Heating } \\
\text { Energy } \\
\text { Consumption } \\
\left(\mathbf{W} / \mathbf{m}^{2}\right)\end{array}$ & $\begin{array}{c}\text { Equivalent Coal } \\
\text { Energy } \\
\text { Consumption } \\
\left(\mathbf{k g} / \mathbf{~ m}^{2}\right)\end{array}$ & $\begin{array}{c}\text { Heating Quantity } \\
\text { during Heating } \\
\text { Season }(\mathbf{M J})\end{array}$ \\
\hline 23.93 & 23.68 & 25.38 & 24.61 & 20.87 & 73240.59 \\
\hline
\end{tabular}

Note: The results in the table are calculated based on the gross floor area. If it is calculated according to the area of use, the heating and heating consumption per unit area of the lightweight timber house is $43.98 \mathrm{~W} / \mathrm{m}^{2}$.

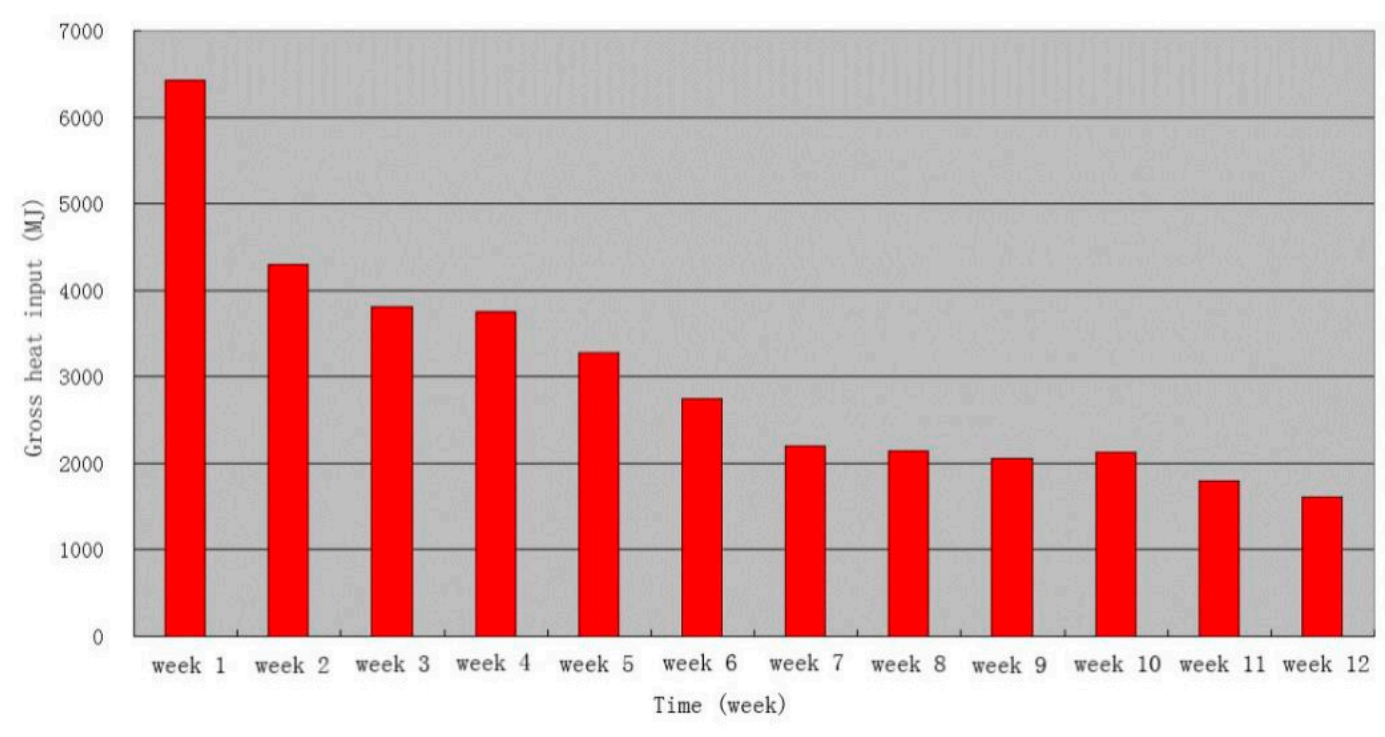

Figure 5. The statistical bar chart of the weekly heating quantity in the lightweight wood timber house. 


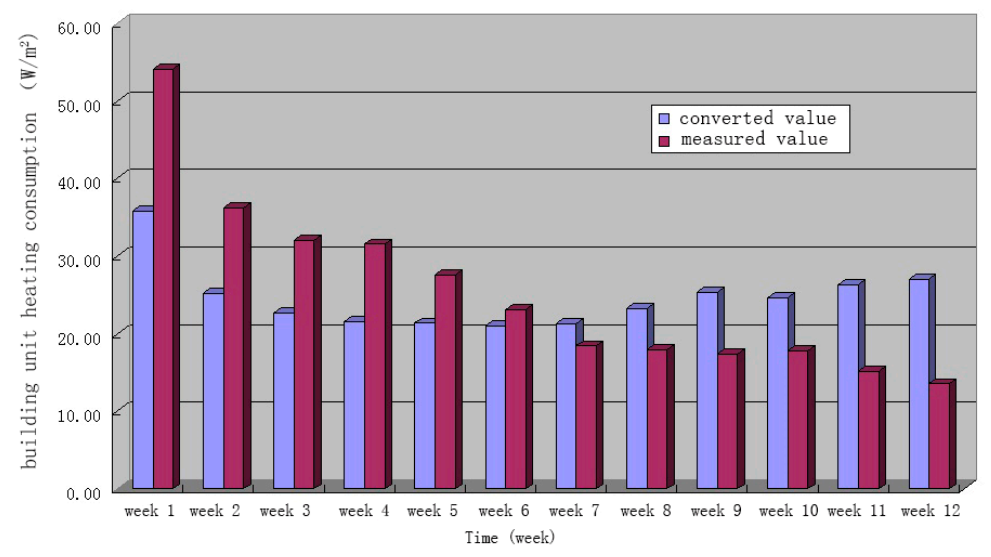

Figure 6. The heat consumption statistics of lightweight wood timber house.

\subsection{The Indoor Average Temperature}

The indoor average temperature $\left({ }^{\circ} \mathrm{C}\right)$ is the measured temperature during heating under normal operating condition of the building. During the heating period, the indoor activities in one or more representative locations were measured for at least $24 \mathrm{~h}$ to find the arithmetic mean of the hourly indoor air temperature value.

The average indoor temperature of a building should be based on the continuous detection of all temperature probes in the room and is calculated using Equation (4):

$$
t_{i a}=\frac{\sum_{j=1}^{n} t_{m, j} \times A_{m, j}}{\sum_{j=1}^{n} A_{m, j}}
$$

where $t_{i a}$ is the Indoor average temperature during the monitoring period, ${ }^{\circ} \mathrm{C} ; t_{m, j}$ is the hourly arithmetic mean of $j$ thermometer measurement temperature during the monitoring, ${ }^{\circ} \mathrm{C} ; A_{m, j}$ is the $j$ thermometer temperature for the heating building area, $\mathrm{m}^{2} ; j$ is the number of the indoor thermometer; and $n$ is the number of thermometers in the building.

According to China energy effiency standard [17], the average indoor temperature during a monitoring duration should not be below a minimum of $16^{\circ} \mathrm{C}$. The maximum should not be higher than $24^{\circ} \mathrm{C}$. Figure 7 shows the rate of increase in the percentage of energy consumption under different indoor temperature when $18{ }^{\circ} \mathrm{C}$ was set as a benchmark indoor temperature.

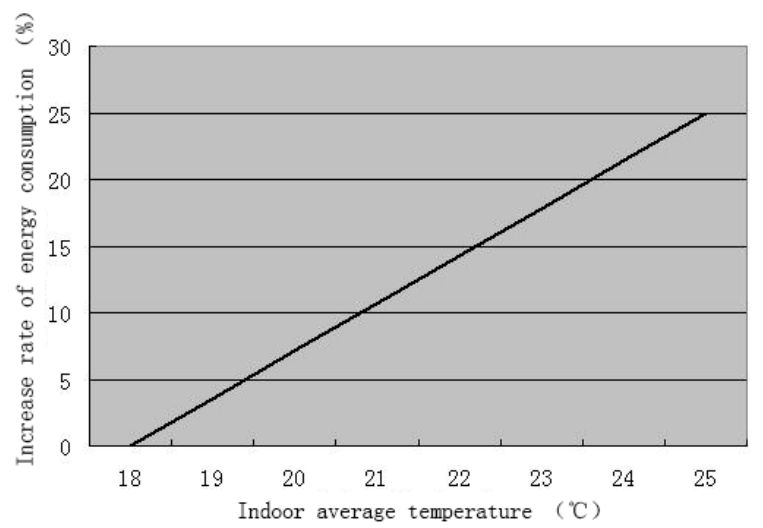

Figure 7. The corresponding increase in energy consumption against different indoor temperatures after a rise above $18{ }^{\circ} \mathrm{C}$. 
As can be seen in Figure 7, if the indoor temperature of the building was reduced from the current $20{ }^{\circ} \mathrm{C}$ to $18{ }^{\circ} \mathrm{C}$, the heating energy consumption would then be reduced by about $6 \%$ and the energy consumption would be reduced by $7.89 \%$. The unit heating energy consumption would be reduced from the original $24.61 \mathrm{~W} / \mathrm{m}^{2}$ to $22.67 \mathrm{~W} / \mathrm{m}^{2}$, the amount of coal consumed would also be reduced accordingly. The indoor temperatures of the lightweight wood-timber house are shown in Table 4, and the temperature curve is shown in Figure 8. In Figure 7, it can be seen that, as the indoor temperature decreases, the energy consumption decreases accordingly. It shows that we could control the indoor temperature between 16 to $24^{\circ} \mathrm{C}$ to achieve thermal comfort, thereby controlling the building energy consumption and reducing coal consumption. In Figure 8, the indoor temperature is basically fluctuating above $20^{\circ} \mathrm{C}$, and the indoor thermal comfort is good. The temperature fluctuation of the south room is larger than that of the north room. The outdoor temperature gradually increases from January to April, but the indoor temperature is basically unchanged. It shows that the outdoor temperature has little effect on the indoor temperature. In Table 4, the temperature of some rooms is higher than $24^{\circ} \mathrm{C}$, which is not conducive to energy saving and requires further control of its temperature. For example, the toilet is above $24{ }^{\circ} \mathrm{C} 70.73 \%$ of the time, while the living room is above $24^{\circ} \mathrm{C} 35.92 \%$ of the time. The temperature of these rooms needs to be adjusted downward to be within the range of $16-24^{\circ} \mathrm{C}$.

Table 4. The statistical interior temperatures in the lightweight wood-timber house.

\begin{tabular}{|c|c|c|c|c|c|c|c|}
\hline \multirow[b]{2}{*}{ Location } & \multicolumn{3}{|c|}{ Test Temperature $\left({ }^{\circ} \mathrm{C}\right)$} & \multicolumn{2}{|c|}{ Less than $16^{\circ} \mathrm{C}$} & \multicolumn{2}{|c|}{ Higher than $24^{\circ} \mathrm{C}$} \\
\hline & $\begin{array}{c}\text { Average } \\
\left({ }^{\circ} \mathrm{C}\right)\end{array}$ & $\begin{array}{l}\text { Minimum } \\
\left({ }^{\circ} \mathrm{C}\right)\end{array}$ & $\begin{array}{l}\text { Maximum } \\
\left({ }^{\circ} \mathrm{C}\right)\end{array}$ & $\begin{array}{c}\text { Occurrence } \\
\text { Time (Minutes) }\end{array}$ & $\begin{array}{l}\text { Proportion } \\
(\%)\end{array}$ & $\begin{array}{c}\text { Occurrence } \\
\text { Time (Minutes) }\end{array}$ & $\begin{array}{l}\text { Proportion } \\
(\%)\end{array}$ \\
\hline Drawing room & 23.06 & 19.81 & 26.13 & 44 & 0.98 & 1609 & 35.92 \\
\hline Office & 19.96 & 19.00 & 21.38 & 80 & 1.8 & 0 & 0 \\
\hline The bar & 20.60 & 18.94 & 22.56 & 69 & 3.75 & 0 & 0 \\
\hline Toilet & 19.18 & 16.31 & 19.94 & 107 & 2.39 & 0 & 0 \\
\hline Radiator chamber & 15.24 & 8.50 & 23.69 & 2587 & 57.77 & 0 & 0 \\
\hline Garage & 13.02 & 8.06 & 23.19 & 3913 & 97.34 & 0 & 0 \\
\hline Main bedroom & 22.30 & 19.94 & 26.81 & 47 & 1.05 & 526 & 11.74 \\
\hline Room 2 & 22.03 & 20.00 & 24.38 & 47 & 1.05 & 71 & 1.08 \\
\hline Room 3 & 21.86 & 18.50 & 29.13 & 63 & 1.41 & 789 & 17.61 \\
\hline Toilet & 25.99 & 21.00 & 30.44 & 31 & 0.69 & 3168 & 70.73 \\
\hline Toilet in main bedroom & 20.40 & 18.63 & 22.75 & 77 & 1.72 & 0 & 0 \\
\hline Walk-in closet & 18.96 & 17.13 & 22.63 & 103 & 2.3 & 0 & 0 \\
\hline Attic & 20.40 & 18.63 & 22.75 & 77 & 1.72 & 0 & 0 \\
\hline $\begin{array}{l}\text { Corridor; Corridor; } \\
\text { upper porch }\end{array}$ & 22.22 & 19.88 & 28.44 & 47 & 1.05 & 614 & 13.71 \\
\hline Basement & 12.97 & 9.44 & 15.25 & 4453 & 99.46 & 0 & 0 \\
\hline Outdoors & -3.09 & -21.06 & 17.94 & & & & \\
\hline
\end{tabular}

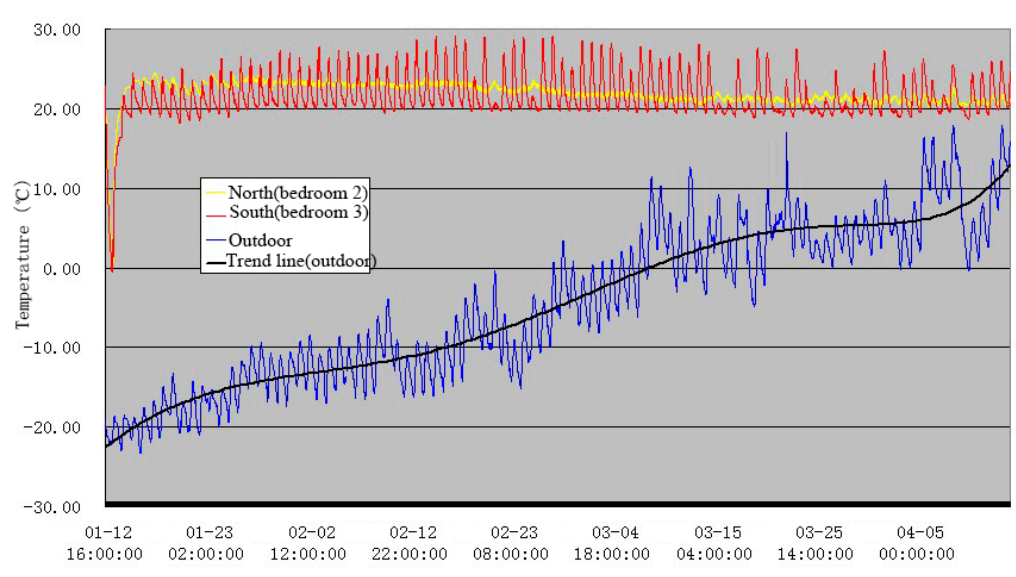

Figure 8. Indoor temperature during the monitoring period, 12 January to 5 April 2008. 


\subsection{Relative Humidity in the Unoccupied Test House}

There is no relative humidity control device in the wood structure building. Therefore, the relative humidity cannot be controlled during the entire test period. We accurately measured and recorded the indoor and outdoor air relative humidity. The average indoor and outdoor air relative humidity is shown in Table 5, and the relative humidity test curve is shown in Figure 9. It shows that the average indoor and outdoor relative humidity was $17.95 \%$ and $55.14 \%$, respectively.

The relative humidity of the indoor air has a certain impact on building energy efficiency. If the relative humidity is too high, the indoor dew point temperature will increase, and some buildings will cause condensation. In addition, if the humidity is too high, it will increase the energy consumption to some extent.

In Table 5 and Figure 9, the indoor humidity is only $17.95 \%$, which is lower than the standard of $30 \%$, and the interior is dry, which is not good for human health and requires humidification. The outdoor humidity is $55.14 \%$, which is relatively humid. The invasion of humid air can increase building energy consumption. Therefore, it is necessary to improve the airtightness of the house and prevent indoor condensation.

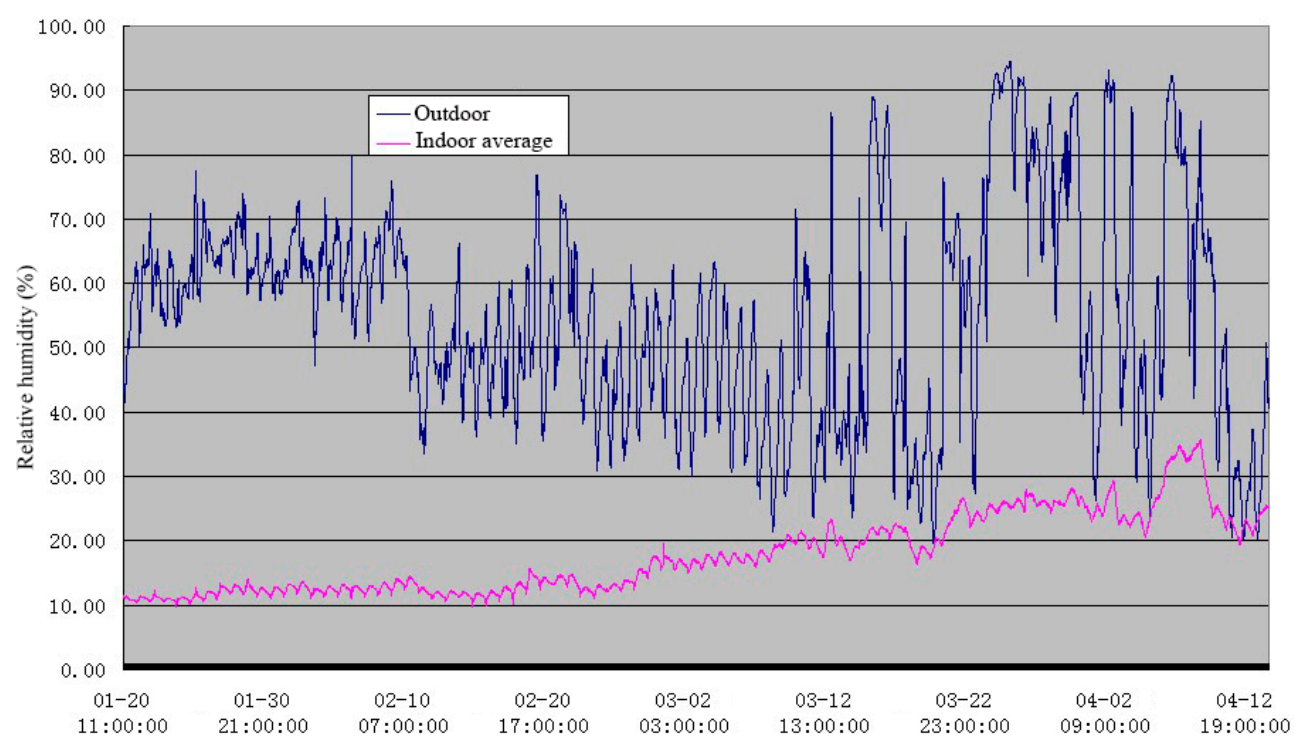

Figure 9. The relative humidity in the unoccupied test house.

Table 5. The relative humidity of indoor and outdoor air.

\begin{tabular}{lcc}
\hline & Outdoor Air Relative Average (\%) & Indoor Air Relative Average (\%) \\
\hline light wood structures & 55.14 & 17.95 \\
\hline
\end{tabular}

\subsection{The Tracking Indoor Temperature Decline with Time due to the Stopped Heating}

The main purpose of the follow-up test of the drop in indoor temperature after time due to an accident is to examine the heat storage capacity of the building, which is particularly important for construction in severe cold regions. Through our test of $19.5 \mathrm{~h}$ of stopping the heating and testing the temperature of each room (sampling once every $10 \mathrm{~min}$, automatic measurement), we found that most of the rooms are close to $0^{\circ} \mathrm{C}$ or lower than $0{ }^{\circ} \mathrm{C}$, indicating that, although the building's heat preservation capacity is very good, the overall heat storage capacity is weak, thus paying special attention to the safety and potential risks of the system, such as the antifreeze of the sanitary facilities, after stopping the heating or power outage due to the accident and the failure of the fan in the future is necessary. It is recommended to increase the equipment fan and other auxiliary heating equipment such as electric heaters. The temperature fluctuation curve is shown in Figure 10. 


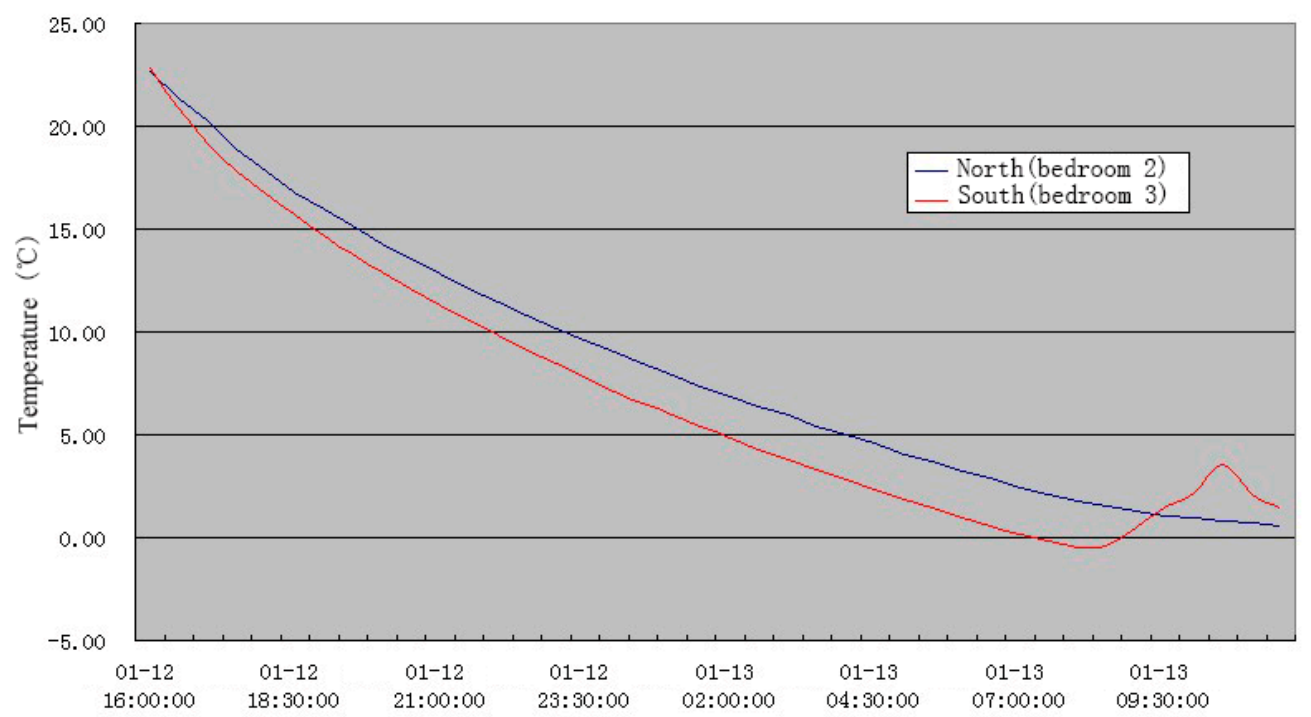

Figure 10. Test curve of indoor temperature drop after the heating stop due to the accident.

\subsection{Indoor Heating Rate after Heating is Restored}

The indoor heating rate test after heating was resumed to examine the heating system capacity. After we stopped the heating of the light wooden houses for $19.5 \mathrm{~h}$, the heating was restored and the room temperature was tracked (sampling once every $10 \mathrm{~min}$, automatic measurement). It is not until after $44 \mathrm{~h}$ that the temperature in each room is stable within the set temperature range. This time is longer than the cooling process. Therefore, we recommend that the heating capacity of the system should be fully considered in the design, and the design heat load and heat dissipation should be increased. The amount of equipment should be set to make the room temperature meet the requirements in a short time. The temperature fluctuation curve is shown in Figures 11 and 12.

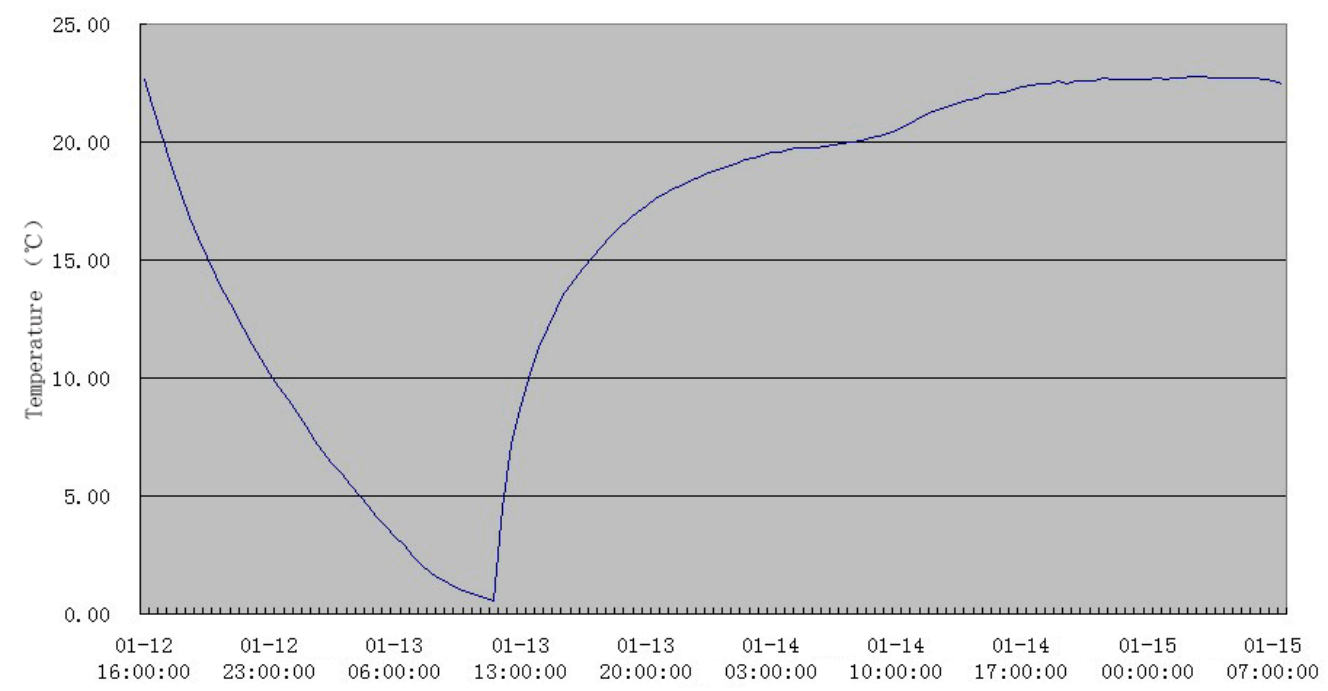

Figure 11. The temperature profile in Bedroom 2 in the north side after heating was restored. 


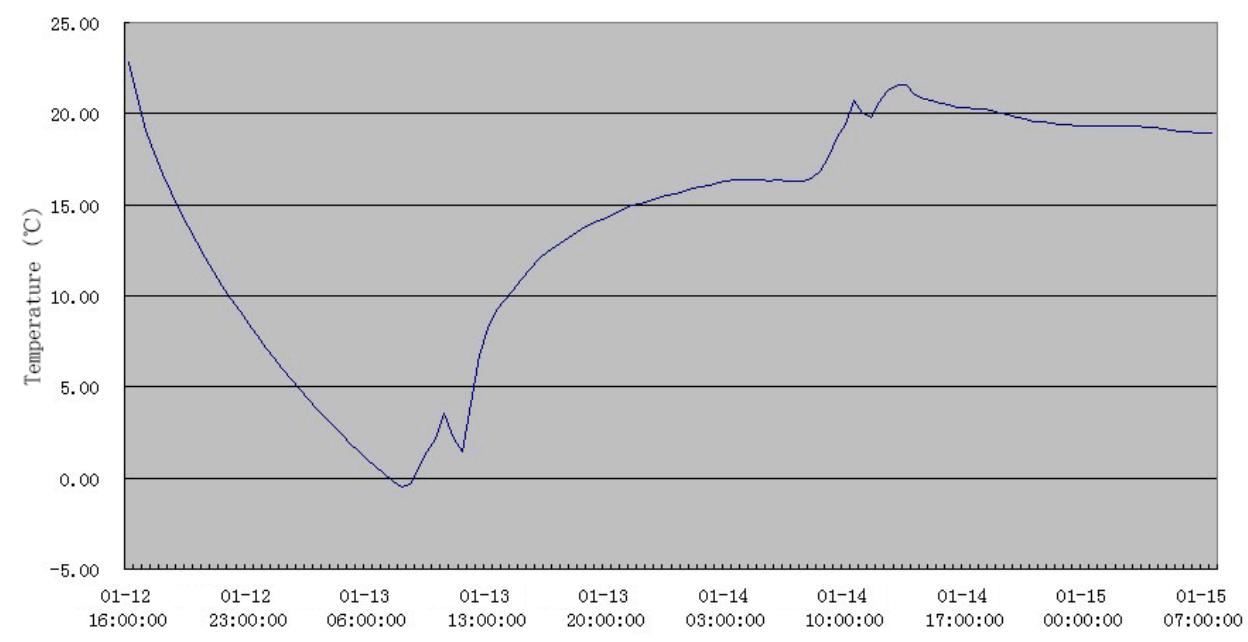

Figure 12. The temperature profile in Bedroom 3 in the south side after heating was restored.

\subsection{Heat Transfer Coefficient of the Enclosed Structure in the Lightweight Timber Structured Housing}

The research team used the heat flow meter method to conduct on-site inspection of the heat transfer coefficient of the enveloped structure of the wooden structure. When the test was completed, the construction time of the building exceeded one year, which met the time requirement of the test; the error of the temperature sensor using the test was less than $0.2^{\circ} \mathrm{C}$. The heat flow and temperature meters are automatic detection equipment, and the additional error of these detection instruments is less than $0.1{ }^{\circ} \mathrm{C}$. We used infrared thermal imager to determine the location of the measuring point and determine the location of the measuring point is not close to the thermal bridge, cracks and air leaks; not directly affected by heating or cooling devices and fans; and avoids direct sunlight. The installation of heat flow meters and temperature sensors met the following two requirements: (1) The heat flow meter is directly installed on the inner surface of the inspected envelope structure and in complete contact with the surface. (2) The temperature sensor is installed on both sides of the examined envelope structure. The inner surface temperature sensor should be installed near the heat flow meter, and the outer surface temperature sensor should be installed at the position corresponding to the heat flow meter. The temperature sensor together with the $0.1 \mathrm{~m}$ lead should be in close contact with the surface under inspection. The emissivity of the sensor surface should be essentially the same as the surface being measured. The test was conducted in the coldest month, and there was no significant change in outdoor temperature during the test period. During the test, the heat flow rate and the internal and external surface temperatures were automatically recorded every $30 \mathrm{~min}$. The detection duration was $96 \mathrm{~h}$. The heat transfer coefficient measurement point layout is shown in Figure 13.

The data analysis used the arithmetic average method. The conditions for using the arithmetic average method are: (1) The difference between the calculated value of the last $R$ and the calculated value of $\mathrm{R}$ before $24 \mathrm{~h}$ is not more than $5 \%$. (2) The calculated value of R within the first INT $(2 \times \mathrm{DT} / 3)$ days and the last same number of days within the test period is not more than $5 \%$ (DT is the number of consecutive days of detection, and INT is an integer). (3) The data to be analyzed are an integral multiple of the $24 \mathrm{~h}$ data. The formula for calculating the thermal resistance of the envelope structure is shown in Equation (5). The calculation results for the heat transfer coefficient of the lightweight wooden structure are shown in Table 6.

It can be seen in Table 6 that the wall heat transfer coefficient is $0.244 \mathrm{~W} / \mathrm{m}^{2} \mathrm{~K}$, which is higher than the standard value of $0.2 \mathrm{~W} / \mathrm{m}^{2} \mathrm{~K}$. The window heat transfer coefficient is $2.487 \mathrm{~W} / \mathrm{m}^{2} \mathrm{~K}$, 
which is higher than the standard value of $2.0 \mathrm{~W} / \mathrm{m}^{2} \mathrm{~K}$. It shows that the heat transfer coefficient of the wood-timber house needs to be further reduced to become more energy efficient.

$$
R=\frac{\sum_{j=1}^{n}\left(\theta_{I j}-\theta_{E j}\right)}{\sum_{j=1}^{n} q_{j}}
$$

where $R$ is the Thermal resistance of the enclosed structures, $\mathrm{m}^{2} \cdot \mathrm{K} / \mathrm{W} ; \theta_{I j}$ is the $j$ th measurement value of surface temperature in the enclosure structure, $\mathrm{K} ; \theta_{E j}$ is the $j$ th measurement value of surface temperature of the surrounding structure, $\mathrm{K}$; and $q_{j}$ is the jth measurement value of the heat flux density, $\mathrm{W} / \mathrm{m}^{2}$.

Table 6. Calculation results of heat transfer coefficient of the enclosure structure of the unoccupied test house.

\begin{tabular}{ccccccc}
\hline & \multicolumn{3}{c}{ The Main Wall } & & \multicolumn{2}{c}{$\begin{array}{c}\text { Plastic Steel Window } \\
\text { (Single Frame Double Glass) }\end{array}$} \\
\cline { 2 - 7 } $\begin{array}{c}\text { Lightweight } \\
\text { Timber House }\end{array}$ & $\begin{array}{c}\text { Thermal } \\
\text { Resistance } \\
\left(\mathbf{m}^{2} \mathbf{K} / \mathbf{W}\right)\end{array}$ & $\begin{array}{c}\text { Resistance of } \\
\text { heat Transfer } \\
\left(\mathbf{m}^{2} \mathbf{K} / \mathbf{W}\right)\end{array}$ & $\begin{array}{c}\text { Heat } \\
\text { Transfer } \\
\text { Coefficient } \\
\left(\mathbf{W} / \mathbf{m}^{2} \mathbf{K}\right)\end{array}$ & $\begin{array}{c}\text { Thermal } \\
\text { Resistance } \\
\left(\mathbf{m}^{2} \mathbf{K} / \mathbf{W}\right)\end{array}$ & $\begin{array}{c}\text { Thermal } \\
\text { Resistance } \\
\left(\mathbf{m}^{2} \mathbf{K} / \mathbf{W}\right)\end{array}$ & $\begin{array}{c}\text { Heat Transfer } \\
\text { Coefficient } \\
\left(\mathbf{W} / \mathbf{m}^{2} \mathbf{K}\right)\end{array}$ \\
\hline $\begin{array}{c}\text { Calculated } \\
\text { value }\end{array}$ & 3.936 & 4.091 & 0.244 & 0.247 & 0.402 & 2.487 \\
\hline
\end{tabular}

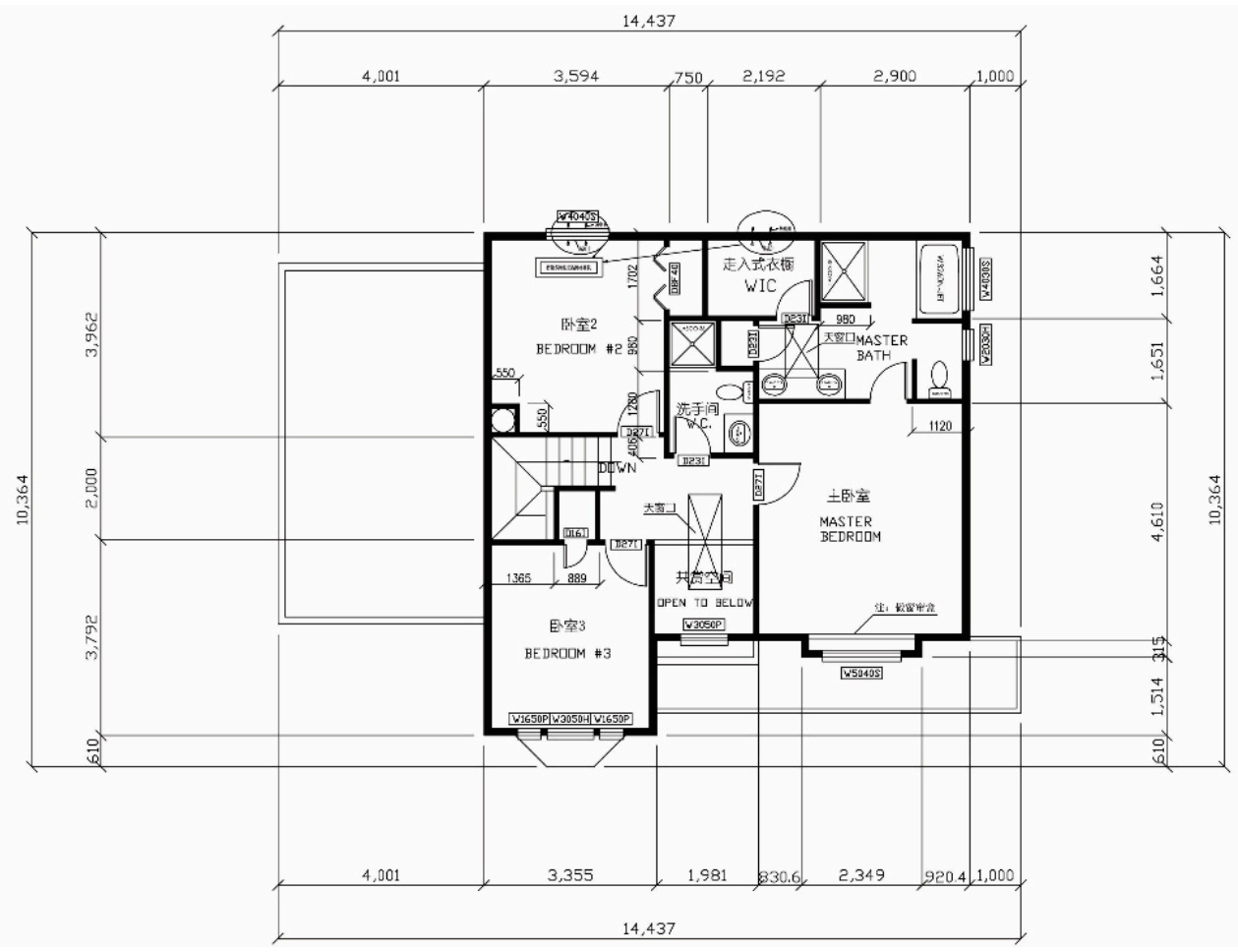

Figure 13. Heat transfer coefficient layout of building envelope (unit: m).

\subsection{The Surface Temperature Distribution in the Thermal Bridge of Building Envelope}

According to the detection scheme of the internal surface temperature distribution of the thermal envelope of the building envelope structure, the infrared thermal imager is used to conduct a general survey of the tested building at night, and then the suspicious sites are repeatedly monitored in 
detail. The infrared test number maps are shown in Figures 14 and 15, and infrared images are shown in Figures 16-21. Through the inspection of wooden houses, it was found that there was no obvious thermal defect. From the infrared thermal image, it can be seen that the corners, wall, roof, and windows of the house have good airtightness and there is no obvious cold air infiltration. It shows that the construction quality and insulation capacity of the house is excellent.

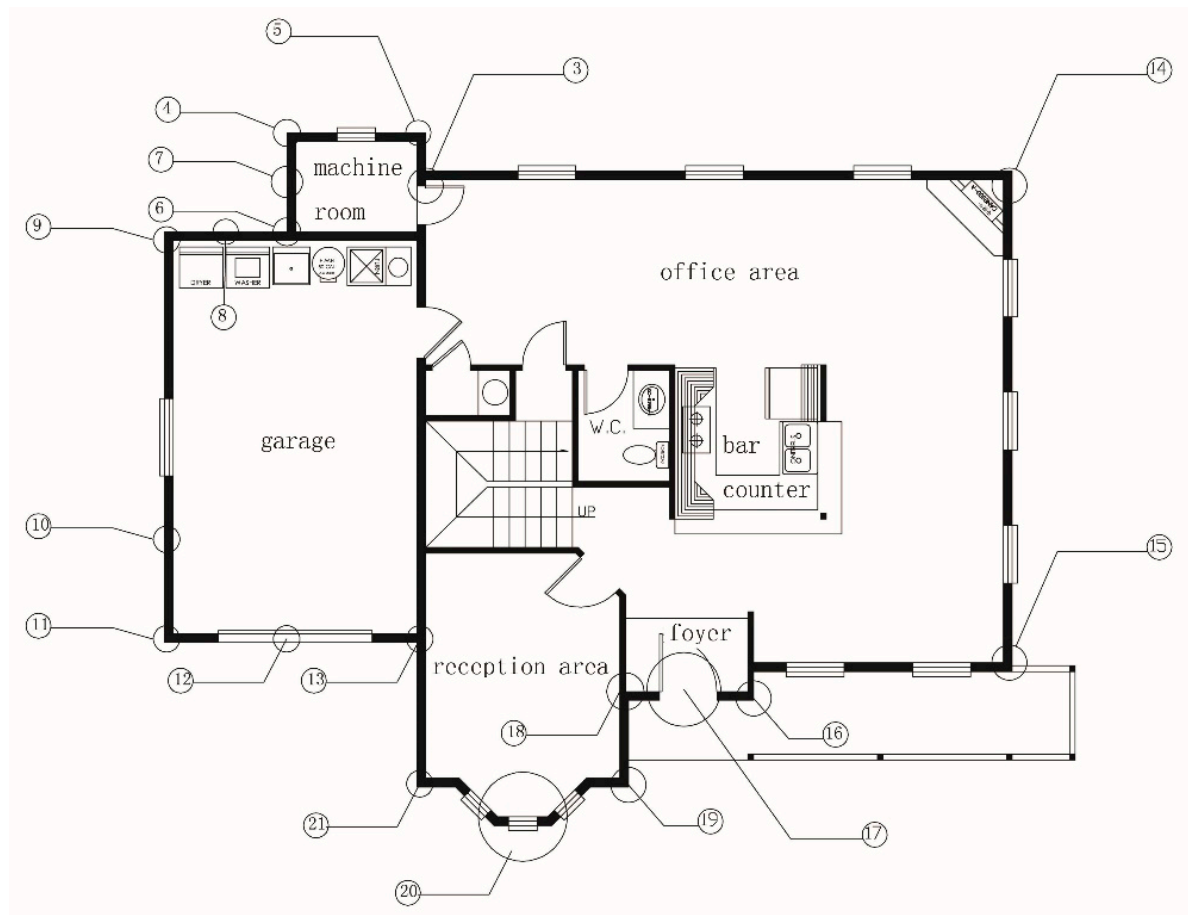

Figure 14. Infrared imaging measurement locations on the ground floor of the unoccupied test house.

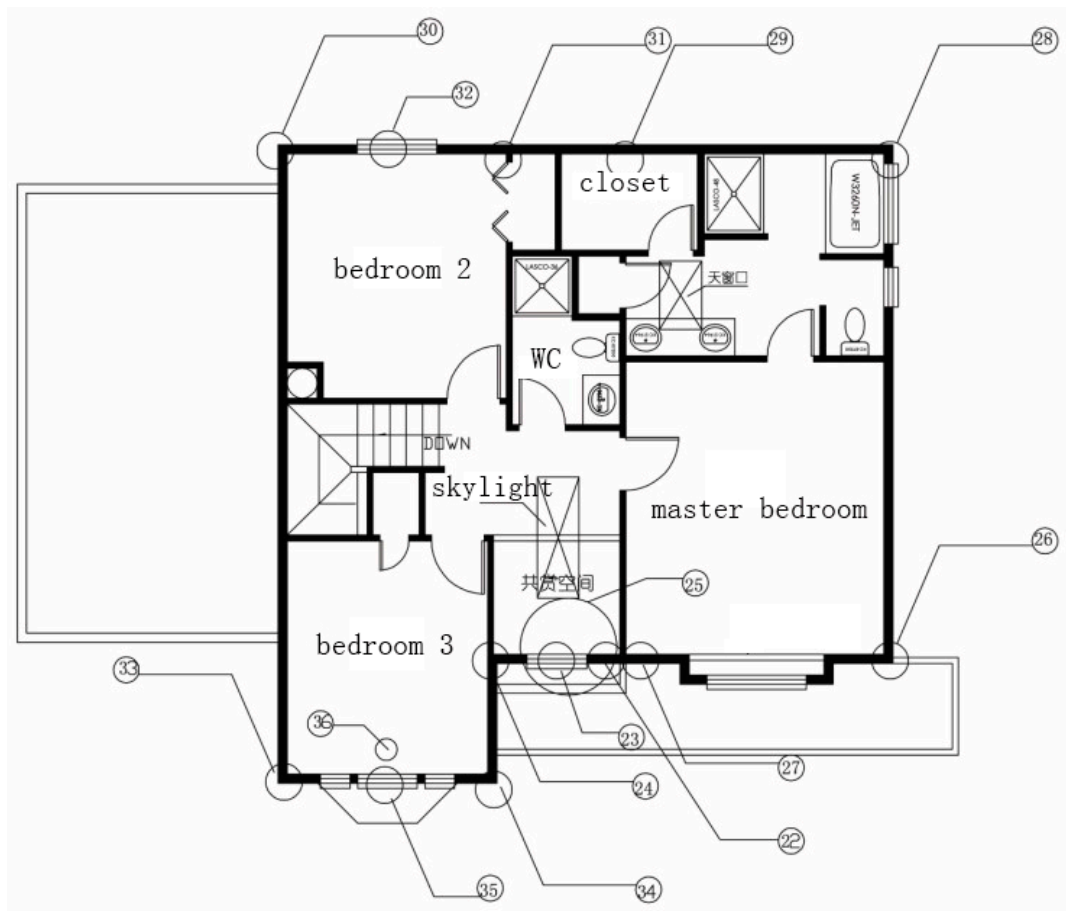

Figure 15. Infrared imaging measurement locations on the upper floor of the unoccupied test house. 


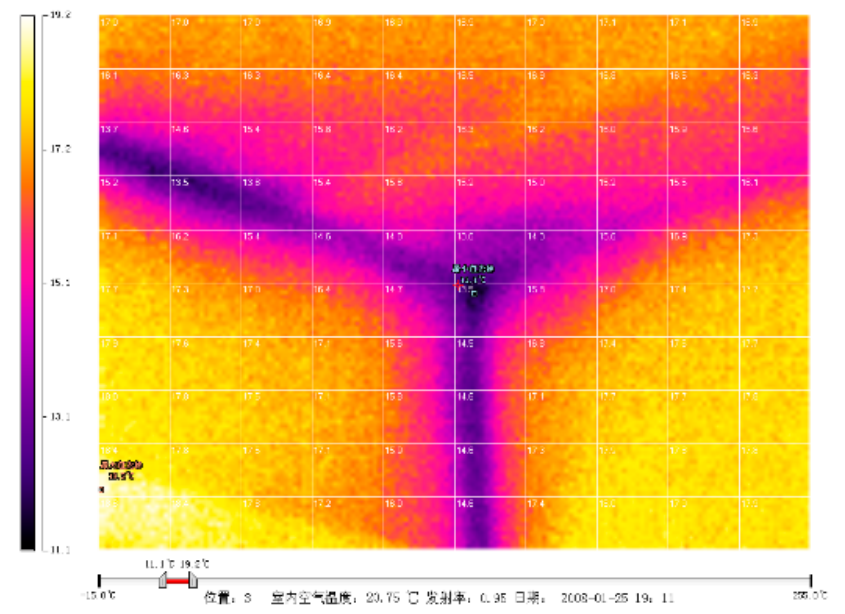

Figure 16. The thermography of the northwestern corner.

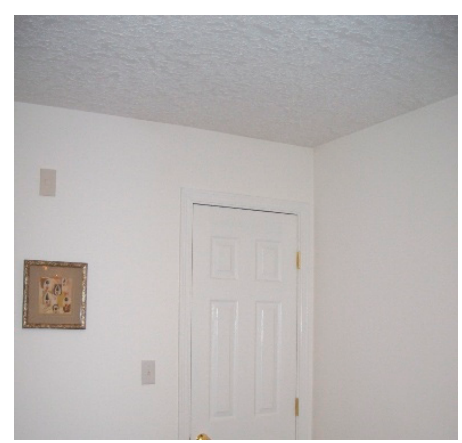

Figure 17. Northwestern corner.

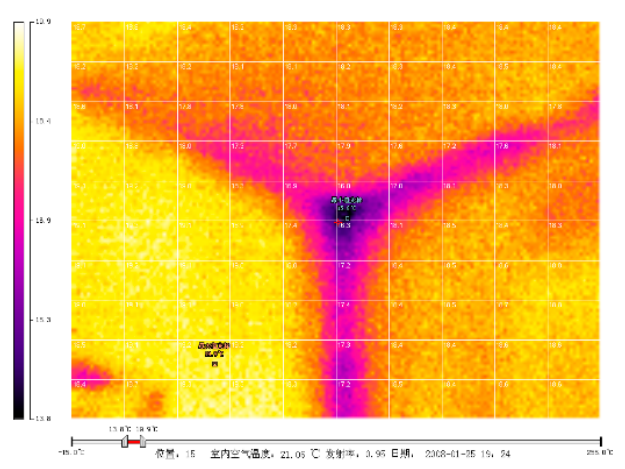

Figure 18. The thermography of the southeastern corner.

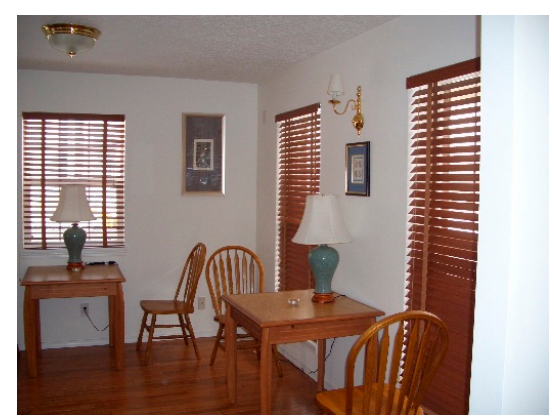

Figure 19. Southeastern corner. 


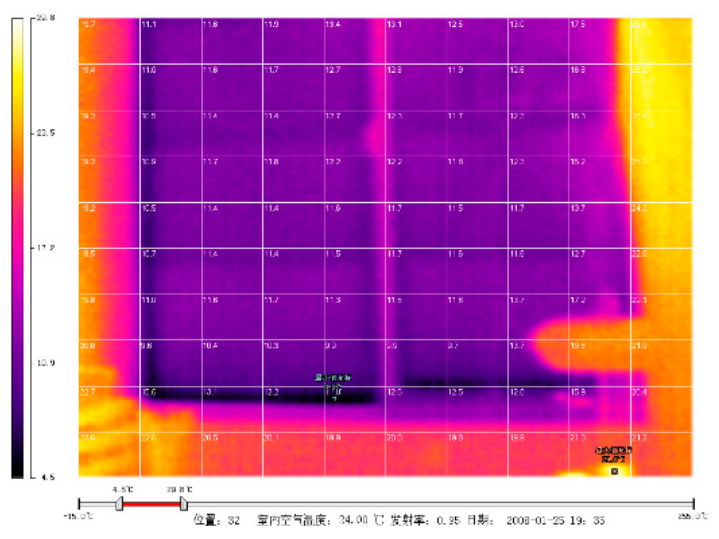

Figure 20. The thermography of the window.

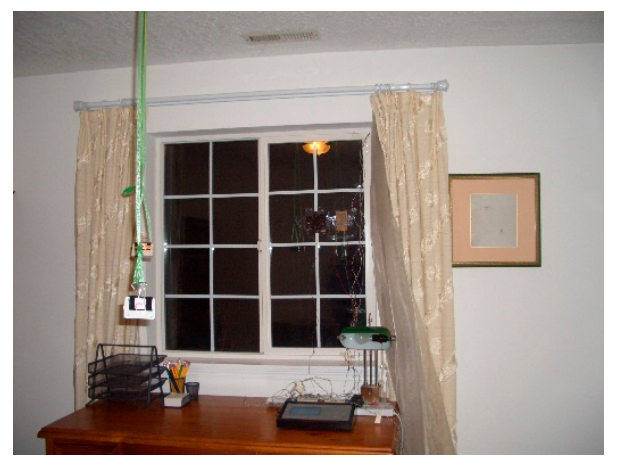

Figure 21. Near the window.

\subsection{The Return Air Volume, Return Air Temperature and Humidity of the Air Conditioning System}

Light wooden houses use air-conditioning systems to send air for heating purposes. The air supply temperature is set according to the indoor air temperature requirements. This test study presupposes that the indoor air temperature is controlled at about $20^{\circ} \mathrm{C}$, and each room and the air-conditioning system send it on time. The temperature and humidity of the return air are shown in Table 7. Table 8 shows the total air supply, return air volume and fresh air volume of the whole building air-conditioning system. The temperature and humidity fluctuation curves are shown in Figures 22 and 23. The instantaneous average inlet water flow of the air conditioning system for heating was $1.217 \mathrm{~m}^{3} / \mathrm{h}$, and the average temperature difference of supply and return water was $3.70{ }^{\circ} \mathrm{C}$. As can be seen in Figure 22, the air-conditioning supply air temperature tends to be stable from 25 February, showing regular fluctuations. Thus, under the combined effect of indoor and outdoor temperatures, the indoor air temperature shows a steady state. As can be seen in Figure 23, the return air temperature of the air conditioner tends to be stable from 25 February, while exhibiting periodic fluctuations, and the stabilization time thereof is consistent with the supply air temperature stabilization time. This shows that, during this period, the thermal performance of the house is stable and the air-conditioning operation is regular. As can be seen in Figure 7, the average supply air temperature is $34.9{ }^{\circ} \mathrm{C}$, the average return air temperature is $21.4^{\circ} \mathrm{C}$, the temperature difference is $13.5^{\circ} \mathrm{C}$, the average air supply humidity is $7.47 \%$, and the return air humidity is $15.03 \%$. It can be seen from the data that the air conditioner temperature is high; it could be reduced to $16-24{ }^{\circ} \mathrm{C}$, thereby reducing air conditioning energy consumption. The humidity of the room is lower than the standard $30 \%$, so the humidity of the building needs to be increased. It can be seen in Table 8 that the ventilation rate of each room is different: the ventilation rates of the reception room and the toilet are the highest, 5.81 times/ $\mathrm{h}$ and 5.44 times/h, respectively; garage and dooryard have the lowest ventilation rates, 1.1 times/h and 1.14 times/h, respectively; and the ventilation rate of the 
bedroom is $1.53-2.56$ times $/ \mathrm{h}$. However, it is higher than the standard ventilation rate of 0.5 times $/ \mathrm{h}$, so the house's ventilation rate can be further reduced, thereby reducing the energy consumption of air conditioning.

Table 7. Air supply and return temperature and air relative humidity of the air conditioning system.

\begin{tabular}{ccccc}
\hline $\begin{array}{c}\text { Average Air Supply } \\
\text { Temperature (\%) }\end{array}$ & $\begin{array}{c}\text { Average Return Air } \\
\text { Temperature }\left({ }^{\circ} \mathrm{C}\right)\end{array}$ & $\begin{array}{c}\text { Supply and Return Air } \\
\text { Temperature Difference }\left({ }^{\circ} \mathrm{C}\right)\end{array}$ & $\begin{array}{c}\text { Average Air Supply } \\
\text { Humidity }(\%)\end{array}$ & $\begin{array}{c}\text { Average Return } \\
\text { Air Humidity }(\%)\end{array}$ \\
\hline 34.90 & 21.40 & 13.5 & 7.47 & 15.03 \\
\hline
\end{tabular}

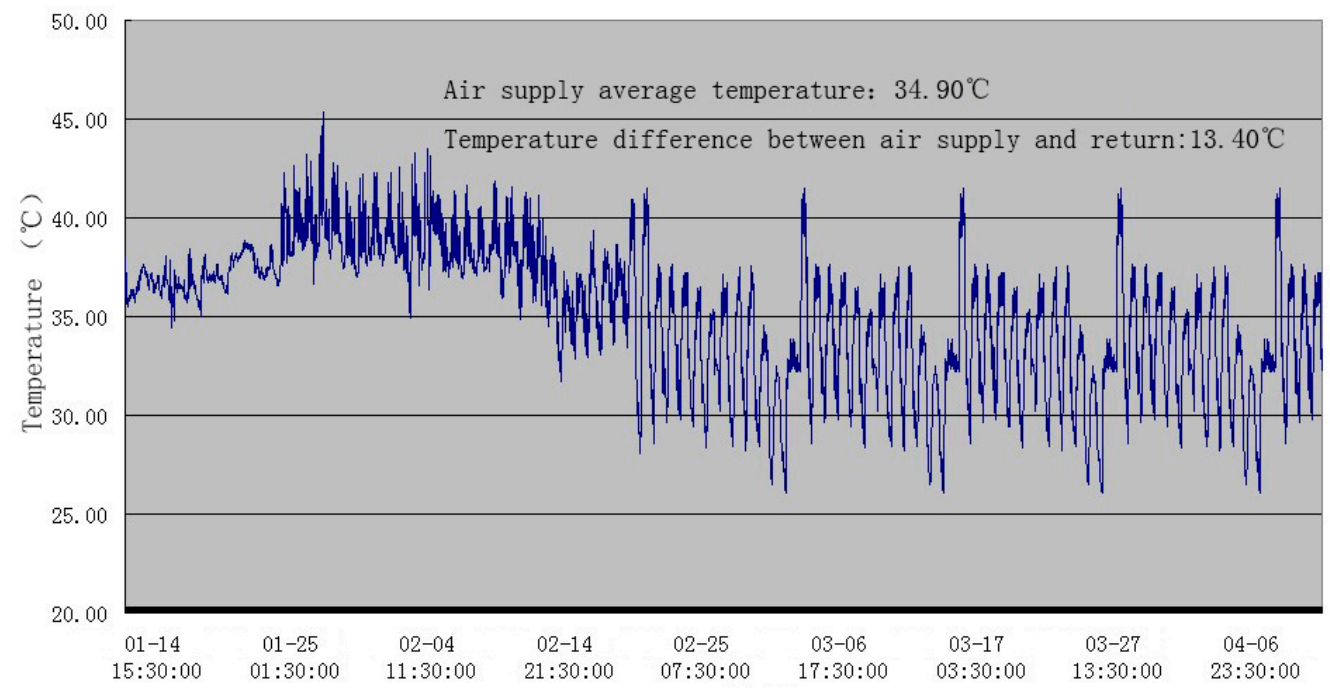

Figure 22. The supply air temperature of the air conditioning system.

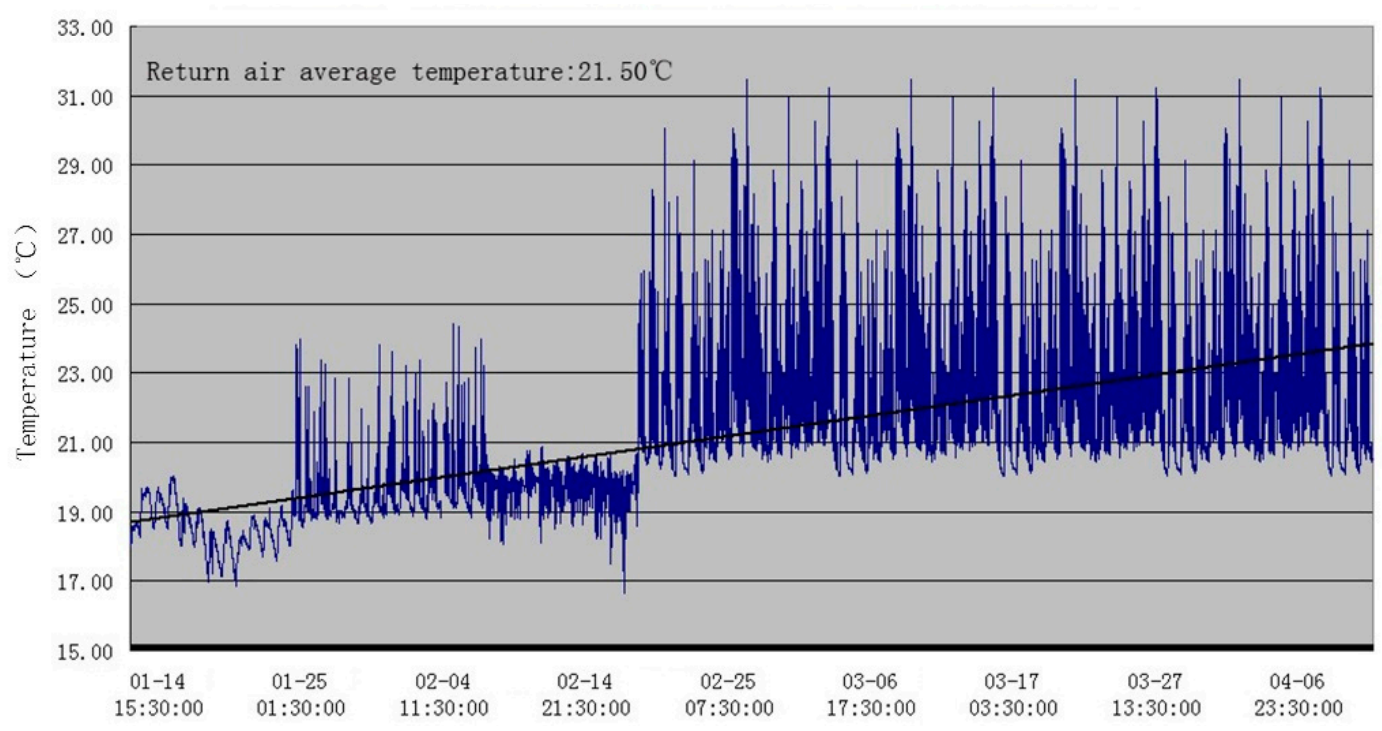

Figure 23. The air return temperature of the air conditioning system. 
Table 8. The air volume of the air conditioning system.

\begin{tabular}{|c|c|c|c|c|c|c|}
\hline No. & Name of Rooms & $\begin{array}{l}\text { Air Volume } \\
\left(\mathrm{m}^{3} / \mathrm{h}\right)\end{array}$ & $\begin{array}{l}\text { Net Height } \\
\text { (m) }\end{array}$ & $\begin{array}{l}\text { Area } \\
\left(\mathrm{m}^{2}\right)\end{array}$ & $\begin{array}{l}\text { Volume } \\
\left(\mathrm{m}^{3}\right)\end{array}$ & $\begin{array}{l}\text { Ventilation Rate } \\
\text { (Times/h) }\end{array}$ \\
\hline 1 & Garage & 87.2 & 3.3 & 24.02 & 79.27 & 1.10 \\
\hline 2 & Office area & 320.4 & 2.43 & 38.8 & 94.28 & 3.40 \\
\hline 3 & Reception Room & 188.7 & 2.43 & 13.36 & 32.46 & 5.81 \\
\hline 4 & Bedroom 2 & 58.7 & 2.41 & 15.96 & 38.46 & 1.53 \\
\hline 5 & Bedroom 3 & 67.6 & 2.41 & 10.95 & 26.39 & 2.56 \\
\hline 6 & Toilet & 46.3 & 2.41 & 3.53 & 8.51 & 5.44 \\
\hline 7 & Principal bedroom & 97.9 & 2.41 & 17.7 & 42.66 & 2.30 \\
\hline 8 & Bathroom & 49.8 & 2.41 & 10.34 & 24.92 & 2.00 \\
\hline 9 & Dooryard & 42.7 & 4.44 & 8.44 & 37.47 & 1.14 \\
\hline 10 & Attic & 37.4 & 1.95 & 7.57 & 14.76 & 2.53 \\
\hline \multicolumn{2}{|c|}{ Total air supply volume $\left(\mathrm{m}^{3} / \mathrm{h}\right)$} & 996.7 & & & - & \\
\hline \multicolumn{2}{|c|}{ Total air return volume $\left(\mathrm{m}^{3} / \mathrm{h}\right)$} & 845.2 & & & - & \\
\hline \multicolumn{2}{|c|}{ Fresh air volume $\left(\mathrm{m}^{3} / \mathrm{h}\right)$} & 151.5 & \multicolumn{4}{|c|}{$\begin{array}{l}\text { The fresh air was permeated naturally by the fresh air inlet set } \\
\text { on the basement window. }\end{array}$} \\
\hline \multicolumn{2}{|c|}{ Fresh air percentage $(\%)$} & 15.2 & & & _- & \\
\hline
\end{tabular}

\section{Conclusions}

In the field test of a house, the average indoor temperature was $20.14{ }^{\circ} \mathrm{C}$, the average indoor air relative humidity was $17.95 \%$, the shape coefficient was 0.63 , and the standard year heat consumption was $24.61 \mathrm{~W} / \mathrm{m}^{2}$. In terms of air conditioning system, the average water flow was $1.217 \mathrm{~m}^{3} / \mathrm{h}$, and the average temperature difference was $3.70{ }^{\circ} \mathrm{C}$.

In terms of building airtightness and healthy ventilation, ventilation frequency was decreased from $0.8 / \mathrm{h}$ to $0.5 / \mathrm{h}$ and unit heat consumption was reduced by about $10 \%$ by improving the air tightness of doors and windows.

The heat transfer coefficient of wall is $0.244\left(\mathrm{~W} / \mathrm{m}^{2} \mathrm{~K}\right)$. The heat transfer coefficient of the upvc-steel window is $2.487 \mathrm{~W} / \mathrm{m}^{2} \mathrm{~K}$. The thermal imagery technique did not find any obvious thermal defect in the construction of the building.

Through the cooling test, it was found that the wood building's heat storage capacity is insufficient, and it is necessary to increase the backup heating equipment. When an unexpected power outage occurs in the building, it can provide emergency heating for the building to prevent the building from freezing.

In sum, light wood-timber structured house can create a comfortable and livable thermal environment for residents in severe cold areas and reduce the heating energy consumption. The research provides a useful guidance for countries and regions in the world with the same latitude.

Author Contributions: B.Z. conceived and designed the experiments. M.Z. analyzed the data and wrote the paper.

Acknowledgments: The paper is supported by "the Fundamental Research Funds for the Central Universities" (No. xjj2017191) and "Scientific Research Support of New Teacher of Xi'an Jiaotong University" (No. JZ1K004). Thanks to the authors that performed the field test in the paper for all their hard work. In addition, thanks to the owner of the house for providing us the field test site.

Conflicts of Interest: The authors declare no conflict of interest.

\section{References}

1. Steinberg, E.; Selle, R.; Faust, T. Connectors for timber-lightweight concrete composite structures. J. Struct. Eng. 2003, 129, 1538-1545. [CrossRef]

2. Němeček, M.; Kalousek, M. Influence of thermal storage mass on summer thermal stability in a passive wooden house in the Czech Republic. Energy Build. 2015, 107, 68-75. [CrossRef] 
3. Yu, S.G.; Kim, S.H.; Seo, J.K.; Kim, S.M. Analysis of Energy Efficiency of Light-weight Wood Frame House and Wooden Passive House Using PHPP. J. Archit. Inst. Korea Plan. Design 2013, 29, 199-207.

4. Stagg, M.S.; Siskind, D.E.; Stevens, M.G.; Dowding, C.H. Effects of repeated blasting on a wood-frame house. BuMines RI 1984, 8896, 82.

5. Marceau, M.L.; VanGeem, M.G. Comparison of the life cycle assessments of an insulating concrete form house and a wood frame house. J. ASTM Int. 2006, 3, 1-11.

6. Burrows, J. Canadian Wood-Frame House Construction; Central Mortgage and Housing Corporation: Ottawa, ON, Canada, 2006.

7. Sass, L. Wood Frame Grammar: CAD Scripting a Wood Frame House; CAAD Futures: Vienna, Austria, 2005.

8. Bai, J.; Li, N.; Duan, P. Finite-Element Mode for Parametric Analysis of Wood Frame Shear Walls. In Proceedings of the 2015 International Conference on Structural, Mechanical and Material Engineering, Dalian, China, 6-8 November 2015.

9. Dodoo, A.; Gustavsson, L. Life cycle primary energy use and carbon footprint of wood-frame conventional and passive houses with biomass-based energy supply. Appl. Energy 2013, 112, 834-842. [CrossRef]

10. Gustavsson, L. Building with wood-Is that a good thing? For. Mankind 2015, 51, 10-15.

11. Cabeza, L.F.; Rincón, L.; Vilariño, V.; Pérez, G.; Castell, A. Life cycle assessment (LCA) and life cycle energy analysis (LCEA) of buildings and the building sector: A review. Renew. Sustain. Energy Rev. 2014, 29, 394-416. [CrossRef]

12. Karimpour, M.; Belusko, M.; Xing, K.; Bruno, F. Minimising the life cycle energy of buildings: Review and analysis. Build. Environ. 2014, 73, 106-114. [CrossRef]

13. Miao, H.E. Thermal environment analysis and energy-saving measures for Minnan red brick and wood big houses. J. Xiamen Univ. Technol. 2015, 3, 017.

14. Mohamed, A.; Hasan, A.; Sirén, K. Fulfillment of net-zero energy building (NZEB) with four metrics in a single-family house with different heating alternatives. Appl. Energy 2014, 114, 385-399. [CrossRef]

15. Viot, H.; Sempey, A.; Pauly, M.; Mora, L. Comparison of different methods for calculating thermal bridges: Application to wood-frame buildings. Build. Environ. 2015, 93, 339-348. [CrossRef]

16. McAlester, V.S. A Field Guide to American Houses: The Definitive Guide to Identifying and Understanding America's Domestic Architecture; Knopf: New York, NY, USA, 2015.

17. JGJ 132-2001: The People's Republic of China Industry Standard Heating Residential Building Energy-Saving Inspection Standards. 